\title{
Adopsi Life Cycle Costing Untuk Bangunan Gedung Diklat Muara Enim
}

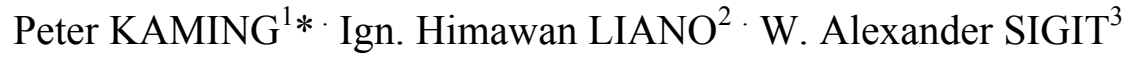 \\ ${ }^{1}$ Staf pengajar, Magister Teknik Sipil, Universitas Atma Jaya Yogyakarta, Yogyakarta, Indonesia, email: \\ Peterkaming82@gmail.com \\ ${ }^{2}$ Mahasiswa, Magister Teknik Sipil, Universitas Atma Jaya Yogyakarta, Yogyakarta, Indonesia, email: \\ ignhimawan1994@gmail.com \\ ${ }^{3}$ Mahasiswa, Magister Teknik Sipil, Universitas Atma Jaya Yogyakarta, Yogyakarta, Indonesia, email: \\ Alexandersigit10@gmail.com
}

\begin{abstract}
Both initial cost for construction and future costs for operation and maintenance of buildings are very important that must be considered by the building owner. Therefore, estimating Life Cycle Cost (LCC) in long term is a must in determining the amount of money spent for the building projects. The objective of this study is to apply a method for LCC to estimate overall costs starting from initial, maintenance, and operational costs. In this study, the LCC also incorporated inflation and bank interest rates in long-term perspective. In this study, LCC was implemented in a building that functioned as a training facility in a building complex in the Muara Enim District. Southern Sumatera. By using the LCC method for estimating cost for a period of 25 years, result shows that the proportion initial cost of construction is $39.12 \%$, maintenance and replacement cost is $16.28 \%$; and operational cost is $44.61 \%$.
\end{abstract}

Keywords: life cycle costing, ISO 15686, maintenance management, building, muara enim district

\section{Pendahuluan}

Suatu kegiatan proyek konstruksi, contohnya pembangunan gedung, selalu berjalan dalam tahapan-tahapan yang jelas. Berjalan pada tahapan yang saling terkait dan memberi dampak. Prosesnya tidak berjalan sendiri namun saling berkaitan. Tahapan-tahapan tersebut dapat dinyatakan dalam sebuah siklus proyek konstruksi. Tipikal tahapan siklus proyek ini berlaku di seluruh dunia tidak terkecuali di Indonesia. Di Indonesia tahapan itu sudah berjalan baik dan menciptakan suatu sistem konstruksi baik sehingga berdampak besar pada sektor ekonomi khususnya investasi. Salah satu perhatian pada aspek teknis tersebut yang menjadi penting dari sudut pandang investasi, bukan saja tahapan perencanaan dan konstruksi, tetapi juga tahapan operasi dan pemeliharaan. Di Indonesia strategi operasi dan pemeliharaan untuk mempertahankan kinerja sistem bangunan masih lemah. Strategi pengelolaan dan pemeliharaan bangunan gedung seharusnya dilakukan sejak dari desain awal perencanaan bangunan. Hal ini penting untuk menjamin bahwa suatu bangunan dapat menjalankan fungsinya sesuai umur yang direncanakan. Kinerja sistem bangunan sendiri sangat bergantung dengan kualitas material dan pengerjaan dari susunan komponen bangunan. Lihat Ervianto (2012).

Strategi pengelolaan dan pemeliharaan seharusnya mampu menjadi alat kontrol dalam menjaga performa kinerja sistem bangunan selama umur layanannya. Metode LCC menjadi salah satu bagian dari strategi pengelolaan dan pemeliharaan bangunan gedung. Metode ini

*penulis korespondensi 
dapat menjadi alat kontrol dengan memberikan estimasi dasar diawal perencanaan gedung yang nantinya digunakan dalam pemeliharaan rutin dalam durasi waktu tertentu. Melalui data awal dan estimasi umur layanan komponen bangunan, dan dengan implementasi metode LCC maka dapat menghasilkan estimasi biaya pemeliharaan dan penggantian berkala pada tiaptiap komponen bangunan pada jangka perencanaan tertentu, misalnya 25 tahunan.

Dengan mengetahui biaya pemeliharaan dan penggantian, serta biaya operasi, maka informasi ini penting bagi pemilik dalam pengambilan keputusan investasi bangunan. Pada kenyataannya, menurut Graham Ive, biaya pemeliharaan dan penggantian serta biaya operasi untuk jangka 25 tahun dari sebuah gedung mampu mencapai 1,5 kali lipat dari biaya awal pembangunannya. Lihat Ive (2006) dalam artikelnya mengenai "Re-examining the Cost and Value Ratios of Owning and Occupying Buildings". Sementara, lanjut Ive, pengeluaran terbesar dari sepanjang masa layan gedung 25 tahun terdapat di biaya tenaga kerja termasuk gaji karyawan tetap. Lihat juga Junus \& Fitria (2015).

Tujuan dari studi ini adalah untuk menghitung biaya bangunan jangka panjang ( 25 tahun) dengan menggunakan metode LCC yang dikembangkan oleh ISO 15686. Studi ini dilakukan dengan menggunakan sebuah bangunan fasilitas pelatihan di kabupaten Muara Enim, Palembang, Sumatera Selatan.

\section{Tinjauan Pustaka}

\section{Metode Life Cycle Costing}

Berdasarkan praktik baku untuk mengukur biaya siklus hidup sebuah sistem bangunan terdapat setidaknya lima cara evaluasi tingkat kinerja sebuah sistem bangunan ditinjau dari aspek ekonomi. Lihat ASTM E917-17. Kelima cara itu untuk analisis LCC adalah; rasio manfaat dan biaya, internal rate, net benefits, payback, dan analisis multiattribute decision. Penggunaan cara-cara tersebut disesuaikan dengan pengukuran dan jenis masalahnya. Pada studi ini, metode LCC dipilih untuk digunakan kerena dianggap mempu merangkum biaya nilai saat ini atau biaya nilai tahunan dari semua biaya bangunan yang memiliki hubungan dengan suatu sistem gedung selama jangka waktu secara spesifik yang dapat ditentukan. Lihat juga Blank \& Tarquin (2005).

Fuller \& Petersen (1996) menyatakan LCC sebagai total biaya diskon dari kepemilikan, operasi, pemeliharaan dan perbaikan serta biaya pembongkaran pada akhir masa layan akhir gedung atau sebuah sistem gedung, bisa pada suatu periode waktu yang sudah ditentukan sebelumnya oleh pemilik. USDA Forest Service, Technology and Development, 2013, mendefinisikan analisis LCC sebagai sebuah metode yang digunakan untuk mengukur efektivitas biaya sepanjang masa layan suatu rancangan gedung, dan dapat dibandingkan opsi desain yang lain.

Dalam Yunus dan Fitria (2015), Life Cycle Costing secara sederhana dapat dinyatakan sebagai suatu metode analisis untuk mengukur nilai ekonomi dari sebuah keputusan pembiayaan suatu proyek infrastruktur, termasuk bangunan gedung. Metode LCC dapat membantu menentukan suatu opsi rancangan dengan menghitung seluruh biaya selama umur layan suatu bangunan yang dinyatakan dalam biaya saat perhitungan itu dilakukan atau dikenal dengan sebutan present value.

Secara garis besar rumusan analisis LCC adalah:

$\mathrm{LCC}=\mathrm{I}+\mathrm{G}-\mathrm{S}+\mathrm{E}+\mathrm{W}+\mathrm{OM}+\mathrm{O}$ 
Keterangan:

I (biaya awal); G (biaya penggantian); S (biaya sisa); E (biaya pemakaian energi); W (biaya pemakaian air); OM (biaya operasi dan pemeliharaan) dan O (biaya okupansi dan lainnya).

Analisis LCC menurut ISO 15686:5 untuk menghitung seluruh biaya keseluruhan pada umur sebuah sistem bangunan (whole life cycle costing) memperhitungkan biaya awal (initial cost), biaya operasi dan pemeliharaan plus penggantian (replacement cost), nilai sisa (residual/salvage value), biaya energi tarif sumber daya (listrik, air, gas, bahan bakar) dan biaya lainnya (pajak, gaji, finansial, dll). Nilai sisa merupakan nilai sebuah gedung pada masa periode studi LCC, meliputi biaya penjualan gedung yang masih dapat digunakan kembali maupun biaya pembuangan akhir gedung. Maka nilai sisa dapat positif bila masih laku dijual, atau negative harus dikurangi karena ada biaya pembuangan.

Aspek waktu atau masa layan gedung yang ditentukan dari siklus hidup suatu bangunan gedung yang bergantung pada masa layan maksimal dari komponen material penyusunnya. Masa pakai gedung inilah yang digunakan sebagai dasar perhitungan waktu dalam metode LCC. Berhubungan LCC berkaitan dengan jangka waktu bangunan, maka dalam analisis juga memperhitungkan discount rate sebagai tingkat bunga yang menunjukkan nilai uang investor terhadap waktu. Lihat Kirk \& Dell'Isolla (1995) dalam bukunya berjudul Life Cycle Costing for Design Professionals, 2nd Edition). Nilai discount rate dapat juga dipengaruhi oleh tingkat inflasi. Lihat juga Kirk \& Dell'Isolla (2003).

\section{Kasus Bangunan Kampus}

Studi kasus yang dilakukan adalah Bangunan Gedung Universitas Atma Jaya Yogyakarta. Penelitian ini bertujuan mengidentifikasi proporsi biaya dan membuat rencana jangka panjang dari gedung kampus berdasarkan metode LCC. Metode yang digunakan adalah 1) persiapan; 2) mengumpulkan data; 3) analisis data dilakukan setelah perhitungan LCC dengan menggunakan spreadsheet; 4) diskusi; dan 5) kesimpulan. Hasil penelitian menunjukkan bahwa ada tiga kelompok yang membentuk LCC: biaya pembangunan gedung, biaya operasi, dan biaya pemeliharaan dan penggantian. Untuk rencana jangka panjang LCC selama 25 tahun diperoleh persentase sebagai berikut, biaya pembangunan awal sebesar Rp. 10.301.450.000 (43\%), biaya operasional Rp. 11.085.000.000 (46\%), biaya perawatan dan penggantian Rp. 2.660.570.080 (11\%). Lihat Kaming (2017)

\section{Proyek Bangunan Rukan Bahu Mall Manado}

Studi ini dipublikasi oleh Kamagi dkk (2013) dengan melakukan analisis Life Cycle Cost pada gedung dari Proyek Bangunan Rukan Bahu Mall di Manado. Tujuan penelitian ini adalah menghitung Life Cycle Cost (LCC) berdasarkan pada komponen bahan bangunan yang digunakan pada saat pembangunan proyek dilaksanakan. Dalam studi kasus ini, bangunan yang ditinjau adalah 9 buah gedung Rukan Bahu Mall Blok-N di Manado, dan komponen bangunan yang akan dikaji LCC adalah dinding, lantai, dan atap dari 9 bangunan rukan tersebut. Melalui proses estimasi ketiga item komponen dinding, lantai dan atap tersebut, maka dihasilkan rincian yaitu biaya modal konstruksi awal adalah Rp. 574.598.000, total biaya pemeliharaan untuk ketiga item tersebut adalah Rp.1.142.620.655, dan biaya pembongkaran sampai saat masa layan ketiga komponen tersebut adalah Rp.5.415.681. Pada studi ini biaya operasional bangunan sudah termasuk dalam pemeliharaan dan penggantian, sehingga komponen biaya pemeliharaan mencapai $66 \%$ dari total biaya siklus hidup bangunan. 


\section{Metodologi}

\section{Pengumpulan Data dan Analisis}

Metode pengumpulan data yang dilakukan dalam penelitian ini adalah 1) Persiapan: melakukan perumusan masalah penelitian, tujuan penelitian, dan mengeksplorasi data dari kantor konsultan untuk mendapatkan data rencana anggaran yang lengkap. 2) Mengumpulkan data: langkah pengumpulkan data ini dilakuakan untuk meperoleh data mendukung penelitian. Melakukan pengumpulan arsip data proyek mulai dari gambar kerja, spesifikasi material dan konsep perancangan hingga pada mengumpulkan data dari kajian studi literatur mengenai standar umur hidup komponen material proyek. 3) Analisis data: dilakukan setelah pengumpulan data, dilakukan perhitungan LCC menggunakan MS-Excel berdasarkan standard ISO 15686 part 5 for LCC. 4) Diskusi: dilakukan dengan rekan kelompok, pelaku profesional konstruksi dan akademisi. 5) Kesimpulan: dilakukan perumusan data.

\section{Objek Penelitian}

Pemerintah Kabupaten Muara Enim dalam rangka meningkatkan kemampuan aparatur memerlukan sarana pendukung berupa gedung tersendiri sebagai tempat untuk menunjang serta mendukung seluruh kegiatan Pendidikan dan Pelatihan bagi para aparatur Pemerintah Kabupaten Muara Enim. Dibangunlah sebuah kompleks gedung pendidikan dan pelatihan (Diklat) Kabupaten Muara Enim yang salah satu bangunan didalamnya terdapat gedung ruang kelas dengan kapasitas ruang 200 orang. Gedung ruang kelas memiliki total luas lantai bangunan mencapai $858 \mathrm{~m}^{2}$. Pembagian ruang fungsional pada bangunan ruang kelas dapat dilihat pada Tabel 1. Bangunan ruang kelas mulai dibangun pada tahun 2013 hingga selesai pada tahun 2015.

Tabel 1. Daftar ruang dalam bangunan ruang kelas

\begin{tabular}{|l|l|c|c|c|}
\hline \multicolumn{1}{|c|}{ No } & \multicolumn{1}{|c|}{ Nama Ruang } & Luasan $\left(\mathrm{m}^{2}\right)$ & Qty & Total Luasan $\left(\mathrm{m}^{2}\right)$ \\
\hline Lantai 1 & 63 & 1 & 63 \\
\hline 1 & Hall & 15 & 2 & 30 \\
\hline 2 & R. Tangga & 15 & 1 & 15 \\
\hline 3 & R. Widyaiswara & 60 & 2 & 120 \\
\hline 4 & R. Kelas I & 45 & 1 & 45 \\
\hline 5 & R. Pengelola & 45 & 1 & 45 \\
\hline 6 & R. Kelas II & 30 & 1 & 30 \\
\hline 7 & Kamar Mandi & 81 & 1 & 81 \\
\hline 8 & Koridor & 30 & 2 & 60 \\
\hline Lantai 2 & 15 & 2 & 30 \\
\hline 1 & R. Diskusi & 20 & 1 & 20 \\
\hline 2 & R Tangga & 10 & 1 & 10 \\
\hline 3 & R. Widyaiswara & 15 & 1 & 15 \\
\hline 4 & R. Operator Sound & 195 & 1 & 195 \\
\hline 5 & Gudang & 30 & 1 & 30 \\
\hline 6 & R. Seminar & 69 & 1 & 69 \\
\hline 7 & Kamar Mandi & \multicolumn{3}{|l|}{} \\
\hline 8 & Koridor & \multicolumn{5}{|l|}{ Total } & 858 \\
\hline
\end{tabular}

Acuan harga material dan upah pekerja yang digunakan sebagai dasar perhitungan menggunakan SNI tahun 2013. Estimasi yang dilakukan menggunakan metode LCCA mengambil jangka periode waktu 25 tahun dengan basis data inisial cost pada rencana anggaran biaya pada tahun 2013. 


\section{Model Metode Life Cycle Cost Analysis}

Model life cycle cost analysis dalam studi ini berpedoman pada ISO 15686: 5 for LCC.

\section{Initial Development Cost (Biaya Pembangunan)}

Biaya pembangunan meliputi semua biaya awal konstruksi mulai dari biaya pekerjaan bangunan internal maupun eksternal dan biaya terkaitan konstruksi lainnya seperti biaya yang dibayarkan oleh klien sehubungan dengan aset bangunan. Initial cost of construction didasarkan pada data SNI harga material dan upah pekerja tahun 2013.

\section{Maintenance Cost}

Maintenance cost meliputi semua biaya penggantian, pemeliharaan dan adaptasi aset yang dibangun. Maintenance cost mencatat semua biaya perubahan komponen utama, biaya pemeliharaan minor sebagai upaya preventif, biaya tunjangan untuk pergantian material yang tidak terduga, hingga biaya peremajaan atau redekorasi bangunan gedung.

\section{Operation Cost}

Semua biaya operasi gedung atau fasilitas yang ada di dalam bangunan gedung. Biaya ini timbul dari kebutuhan bangunan itu sendiri bukan biaya operasi penghuninya. Biaya operasi meliputi biaya jasa cleaning service, biaya jasa satpam dan jaga malam, dan biaya energi. Biaya energi misalnya seperti biaya listrik, air, bahan bakar dan gas.

\section{Hasil dan Diskusi}

\section{Analisis Data}

Data acuan untuk mengetahui umur hidup komponen yang digunakan pada bangunan diperoleh melalui kajian literatur dari basis data penelitian yang serupa (simillar) dan kajian dari data klaim produk produsen.

Tabel 2. Daftar umur layan komponen bangunan

\begin{tabular}{|l|l|r|}
\hline Kelompok & Komponen Bangunan & Umur Layan (tahun) \\
\hline Atap & Streel Roof Frame & 30 \\
\hline & Roof Clay Tile & 20 \\
\hline & Gutter & 15 \\
\hline Dinding & Wall Paint & 8 \\
\hline & Aluminium Paint & 12 \\
\hline & Wood Paint & 15 \\
\hline & Frame Aluminium & 15 \\
\hline & Door Aluminium & 15 \\
\hline & Timber Frame & 30 \\
\hline & Timber Door & 30 \\
\hline & Timber Window & 30 \\
\hline & Door and Window Glass & 20 \\
\hline Lantai & Granit & 20 \\
\hline & Ceramic & 20 \\
\hline Plafon & Gypsum & 15 \\
\hline & GRC & 18 \\
\hline Sanitasi & Wastafel & 8 \\
\hline & Stainless Steel Sink & 12 \\
\hline & Water Crane & 3 \\
\hline & Water Closet & 15 \\
\hline & Shower & 8 \\
\hline & &
\end{tabular}




\begin{tabular}{|l|l|r|}
\hline Kelompok & Komponen Bangunan & Umur Layan (tahun) \\
\hline & Floor Drain & 8 \\
\hline & PVC pipe & 30 \\
\hline Asesori & Slot Door \& Window & 10 \\
\hline & Handle Door \& Window & 10 \\
\hline & Hinge Door \& Window & 20 \\
\hline & Lamp Standart & 5 \\
\hline & Lamp Down Light & 5 \\
\hline & Wall Stop Contact & 20 \\
\hline & Saclar Single & 20 \\
\hline & Saclar Multiple & 20 \\
\hline & Fitting & 20 \\
\hline & Lift & 30 \\
\hline & Fire Alaram & 30 \\
\hline & Telephon & 15 \\
\hline & CCTV & 30 \\
\hline & Water Heater & 15 \\
\hline & AC & 15 \\
\hline
\end{tabular}

* sumber: service life for material component (Kaming \& Marliansyah, 2015).

Acuan kajian literatur yang digunakan mengacu pada data service life for material component. Lihat Kaming \& Marliansyah, (2015), dan Kaming (2017). Tabel 2 menjelasan detail masing-masing umur layan komponen bangunan.

\section{Perhitungan Life Cycle Cost}

Initial cost of construction yang diperoleh dari pihak konsultan (PT. Multi Visi Karya) pada tahun 2013 adalah Rp. 3.695.914.329. Detail nilai biaya pada setiap pekerjaan dapat dilihat di Tabel 3. Biaya ini mencakup semua biaya konstruksi sesuai dengan data rencana anggaran biaya bangunan gedung.

Tabel 3. Biaya pembangunan

\begin{tabular}{|l|l|c|r|}
\hline No & Uraian Pekerjan & Proporsi & Total Biaya (Rp.) \\
\hline I & P. Persiapan & $3,33 \%$ & 123.074 .000 \\
\hline II & P. Galian \& Urugan & $2,52 \%$ & 93.244 .428 \\
\hline III & P. Pasangan dan Plesteran & $16,99 \%$ & 62.8015 .154 \\
\hline IV & P. Struktur Beton & $42,26 \%$ & 1.561 .824 .267 \\
\hline V & Pekerjaan Kusen Pintu dan Jendela & $6,45 \%$ & 238.288 .215 \\
\hline & P. Pelapis Dinding, Realing dan Plin & $8,42 \%$ & 311.228 .530 \\
\hline VII & Pekerjaan Plafon & $4,67 \%$ & 172.433 .363 \\
\hline VIII & P. Instalasi dan Mekanikal Elektrikal & $4,41 \%$ & 162.941 .707 \\
\hline IX & P. Pengecatan & $3,45 \%$ & 127.600 .835 \\
\hline X & Pekerjaan Sanitar & $0,89 \%$ & 32.803 .947 \\
\hline XI & Pekerjaan Drainase & $1,71 \%$ & 63.154 .456 \\
\hline XII & Pekerjaan Lain-lain & $0,02 \%$ & 780.351 \\
\hline XIII & Pekerjaan Atap dan Penutup Atap & $2,88 \%$ & 180.525 .071 \\
\hline & & $100 \%$ & 3.695 .914 .329 \\
\hline
\end{tabular}

Maintanace cost mengacu pada estimasi jangka waktu 25 tahun terhitung dari tahun 2015 hingga 2040. Gedung mulai dibangun tahun 2013 selesai 2015. Perhitungan metode LCCA pada setiap pekerjaan penggantian, pemeliharaan dan adaptasi dapat dilihat pada Tabel 4 . Hasil analisis yang diperoleh dengan mempertimbangkan nilai inflasi 4 persen per tahun mencapai nilai sebesar Rp. 1.441.657.525. Biaya design \& construction contingency, risk 
allowance, dan overhead \& profit telah dimasukan dalam total biaya anggaran maintenance cost tersebut.

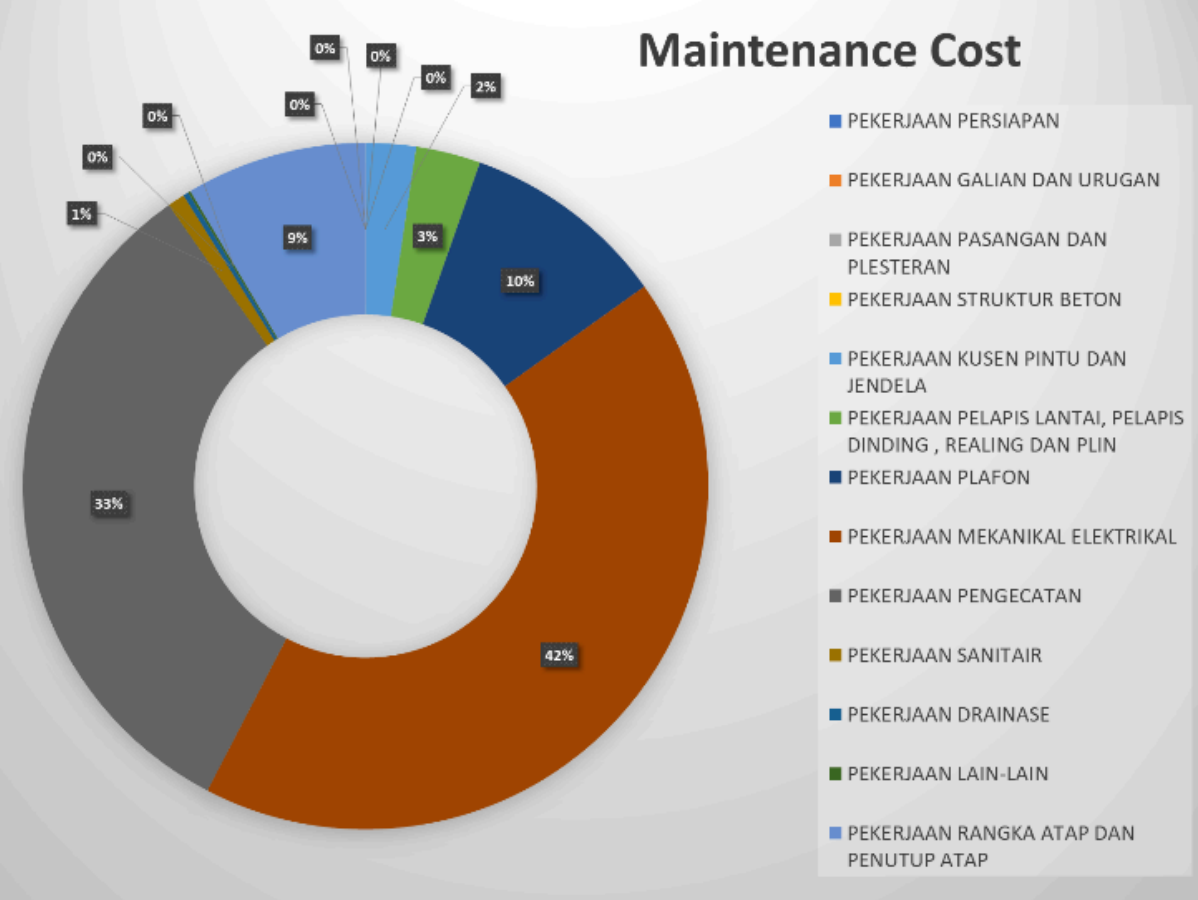

Gambar 1. Proporsi biaya penggantian dan pemeliharaan pada kelompok komponen bangunan.

Tabel 4. Biaya maintenance dan replacement

\begin{tabular}{|c|c|c|c|}
\hline No. & Uraian Pekerjaan & Tahun ke* & Tot Biaya (Rp.) \\
\hline I & Pekerjaan Persiapan & 0 & - \\
\hline II & P. Galian \& Urugan & 0 & - \\
\hline III & Pekerjaan Pasangan dan Plesteran & 0 & - \\
\hline IV & P. Struktur Beton & 0 & - \\
\hline $\mathrm{V}$ & Pekerjaan Kusen dan Jendela & & \\
\hline 1 & Kusen dan daun pintu P3 + Aksesoris (WC) & 20 & 22.094 .078 \\
\hline 2 & kusen dan daun pintu P1 + Aksesoris (Pantry) & 20 & 8.096 .033 \\
\hline VI & Pekerjaan Pelapis Lantai,Dinding, Realing dan Plin & & \\
\hline 1 & Keramik lantai KM/WC ukuran $20 \times 20$ & 20 & 17.792 .354 \\
\hline 2 & Keramik dinding ukran $20 \times 25$ & 20 & 21.068 .069 \\
\hline VII & Pekerjaan Plafon & & \\
\hline 1 & Langit-langit gypsumboard & 7 & 111.315 .439 \\
\hline 2 & Langit-langit kalsiboard & 7 & 12.328 .075 \\
\hline \multirow[t]{2}{*}{ VIII } & Pekerjaan Mekanikal Elektrikal & & \\
\hline & Instalasi Air Besih & & \\
\hline \multirow[t]{2}{*}{1} & Jaringan pipa air, pipa PVC dia $3 / 4 "$ & 8 & 90.518 .181 \\
\hline & Pekerjaan Instalasi Air Kotor & & \\
\hline 1 & Jaringan air kotor, pipa PVC dia 3" & 8 & 8.821 .722 \\
\hline 2 & Jaringan air tinja, pipa PVC 4" & 8 & 10.837 .368 \\
\hline 3 & Bak Air Kotor & 10 & 45.100 .000 \\
\hline \multirow[t]{2}{*}{4} & Biofil BF-08 kap. 2145 lt & 8 & 80.850 .000 \\
\hline & Pekerjaan Elektrikal & & \\
\hline 1 & Intalasi listrik titik lampu dan stop kontak & 10 & 31.574 .400 \\
\hline 2 & Pemasangan stop kontak & 20 & 1.509 .200 \\
\hline
\end{tabular}




\begin{tabular}{|c|c|c|c|}
\hline No. & Uraian Pekerjaan & Tahun ke* & Tot Biaya (Rp.) \\
\hline 3 & Pas. Lampu TL 2 x $18 \mathrm{~W}$ & 5 & 94.421 .250 \\
\hline 4 & Pas. Lampu SL $14 \mathrm{~W}$ & 5 & 16.802 .500 \\
\hline 5 & Pas. Lampu $8 \times 8 \mathrm{~W}$ & 5 & 67.105 .500 \\
\hline 6 & Pas. Saklar tunggal & 20 & 128.700 \\
\hline 7 & Pas. Saklar ganda/double & 20 & 2.672 .450 \\
\hline 8 & Kabel instalasi (Kabel Fender NYY 4 x 16 mm²) $^{2}$ & 10 & 10.560 .000 \\
\hline 9 & Pemasangan stop kontak AC & 20 & 627.500 \\
\hline 10 & $\mathrm{AC}$ & 15 & $80.000 .000,00$ \\
\hline IX & P. Pengecatan & & \\
\hline 1 & Cat dinding dalam & 8 & 273.148 .094 \\
\hline 2 & Cat dinding luar & 5 & 81.878 .384 \\
\hline 3 & Cat Plafond & 7 & 56.162 .522 \\
\hline 4 & Cat list plafond & 7 & 4.364 .860 \\
\hline $\mathrm{X}$ & Pekerjaan Sanitar & & \\
\hline 1 & Pasang kran air 3/4" & 3 & 10.385 .760 \\
\hline XI & Pekerjaan Drainase & & \\
\hline 1 & Pemasangan Roofdrain & 8 & 1.915 .155 \\
\hline 2 & Pipa drainase 4" & 8 & 1.336 .114 \\
\hline XII & Pekerjaan Lain-lain & & \\
\hline 1 & Railing tangga, kayu bengkirai $6 / 12$ profil & 10 & 1.560 .702 \\
\hline XIII & Pekerjaan Rangka Atap dan Penutup Atap & & \\
\hline 1 & Pemasangan atap genteng metal berpasir & 10 & 81.643 .051 \\
\hline 2 & Pemasangan genteng bubungan berpasir & 10 & 12.812 .572 \\
\hline 3 & Listplank ukuran 3 x $20 \mathrm{~cm}$ & 10 & 14.362 .002 \\
\hline \multicolumn{3}{|c|}{ Total Maintanance Cost } & 1.193 .782 .086 \\
\hline \multicolumn{3}{|c|}{ Design \& Construction contingency } & 35.813 .467 \\
\hline \multicolumn{3}{|c|}{ Risk Allwance } & 47.751 .283 \\
\hline \multicolumn{3}{|c|}{ Management Cost } & - \\
\hline \multicolumn{3}{|c|}{ Overhead \& Profit } & 59.689 .104 \\
\hline \multicolumn{3}{|c|}{ Grand Total } & 1.426 .635 .936 \\
\hline \multicolumn{4}{|c|}{ Discount Factor $-3,5 \%$} \\
\hline \multicolumn{3}{|c|}{ Present Value } & 855.353 .777 \\
\hline \multicolumn{3}{|c|}{ Inflasi $-4 \%$} & \\
\hline \multicolumn{3}{|c|}{ Grand Total Life Cycle (25 Years) } & 1.537 .976 .018 \\
\hline
\end{tabular}

Catatan: * Tahun pengeluaran biaya.

Pada maintanance cost diketahui bahwa biaya untuk perawatan dan penggantian pekerjaan mekanikal elektrikal menjadi yang paling besar diikuti kemudian biaya perawatan pekerjaan pengecatan, pekerjaan plafon dan rangka atap.

Biaya operasional gedung dengan memperhitungkan nilai inflasi 4 persen mencapai nilai sebesar Rp 4.214.520.300. Komponen biaya ini meliputi biaya jasa cleaning service, satpam dan penjaga malam dan biaya energi. Biaya energi yang terhitung dalam operational cost meliputi listrik, telpon dan internet, serta bahan bakar generator. Detail pembagian pada setiap komponen pekerjaan dapat dilihat pada Tabel 5, dan Gambar 2.

Tabel 5. Operational cost

\begin{tabular}{|l|l|l|l|r|}
\hline No. & Kelompok & Jmlh - Sat & Harga Satuan & \multicolumn{2}{|l|}{ Jumlah Harga } \\
\hline 1. & Cleaning Service & 1.750 .000 & 3.500 .000 \\
\hline & CS & 2 Orang & 250.000 & 250.000 \\
\hline & $\begin{array}{l}\text { Bahan \& } \\
\text { Alat }\end{array}$ & 1 Ls & \\
\hline
\end{tabular}




\begin{tabular}{|c|c|c|c|c|}
\hline No. & Kelompok & Jmlh - Sat & Harga Satuan & Jumlah Harga \\
\hline 2. & \multicolumn{4}{|c|}{ Security dan Jaga Malam } \\
\hline & Satpam & 2 Orang & 1.750 .000 & 3.500 .000 \\
\hline & Alat & $1 \mathrm{Ls}$ & 350.000 & 350.000 \\
\hline 3. & \multicolumn{4}{|c|}{ Utilitas / Biaya Energi } \\
\hline & Listrik & $1 \mathrm{Ls}$ & 2.000 .000 & 2.000 .000 \\
\hline & $\begin{array}{l}\text { Telpon dan } \\
\text { Internet }\end{array}$ & $1 \mathrm{Ls}$ & 900.000 & 900.000 \\
\hline & Generator & $1 \mathrm{Ls}$ & 450.000 & 450.000 \\
\hline $\mathrm{A}$ & \multicolumn{2}{|c|}{ Total per Bulan $(1+2+3)$} & & 12.500 .000 \\
\hline $\mathrm{B}$ & \multicolumn{2}{|c|}{ Total per Tahun (A x 12) } & & 150.000 .000 \\
\hline $\mathrm{C}$ & \multicolumn{2}{|c|}{$\begin{array}{l}\text { Total Cost Over } 25 \text { Tahun (B x } \\
25)\end{array}$} & & 3.225 .000 .000 \\
\hline \multicolumn{5}{|c|}{ Inflasi } \\
\hline \multicolumn{3}{|c|}{ Total Operation Cost (25 Tahun) } & & 4.214 .520 .300 \\
\hline
\end{tabular}

Berdasarkan presentasi pada initial cost, maintanance cost, dan operational cost dapat diperoleh proporsi dalam bentuk presentase pada masing-masing kelompok biaya pada pekerjaan bangunan gedung ruang kelas di kompleks gedung diklat Kabupaten Muara Enim. Perhitungan metode LCC menunjukkan nilai operational cost adalah biaya yang paling besar seperti disajikan pada Gambar 3.

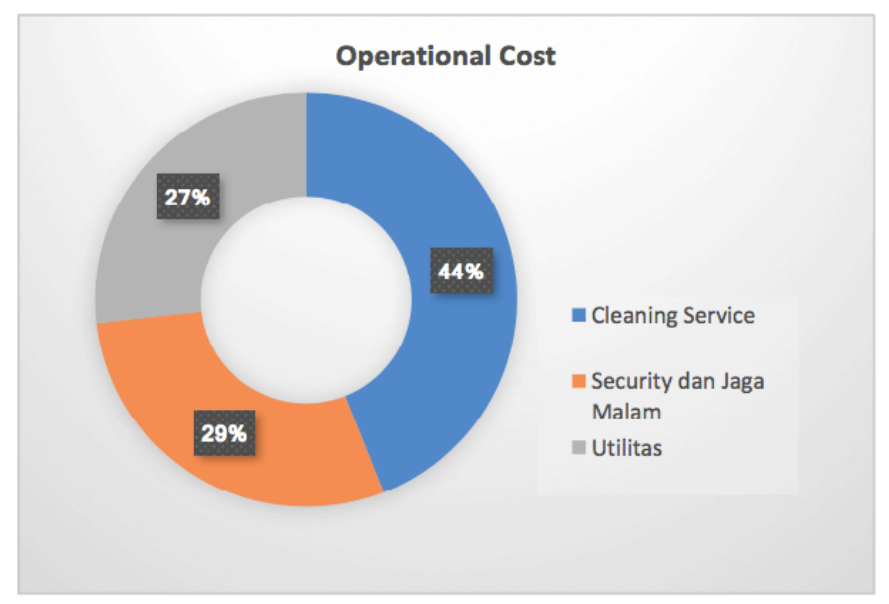

Gambar 2. Proporsi biaya operasi dari bangunan

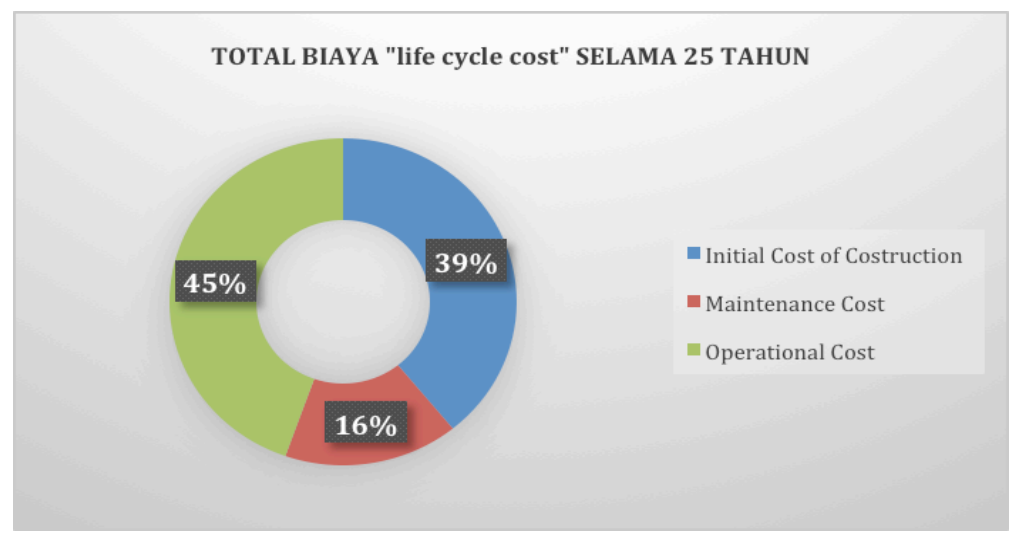

Gambar 3. Proporsi LCC selama 25 tahun 


\section{Kesimpulan}

Perhitungan melalui metode LCCA yang dilakukan pada bangunan gedung ruang kelas di kompleks gedung diklat Kabupaten Muara Enim terbagi menjadi tiga kelompok estimasi biaya yaitu Initial cost of Construction sebesar Rp. 3.695.914.330 (39,12\%), Maintenance and replacement (M\&R) Cost sebesar Rp. 1.537.976.018 (12,39\%) dan Operational Cost sebesar Rp. 6.496.761.693 (44,61\%). Studi ini mengkonfirmasi sinyalir pendapat dari Graham Ive (2006) yang menyatakan bahwa biaya operasional ditambahdengan biaya maintenance and replacement (M\&R) bisa mencapai 1.5 kali lipat dari biaya awal pembangunan.

Studi ini memberikan rekomendasi sebagai berikut. Kinerja sistem bangunan selama umur layan gedung menjadi hal penting dalam aspek ekonomi dari sudut pandang investasi. Penelitian serupa penting dilakukan sebagai landasan dasar pengambilan keputusan dalam pengadaan suatu proyek, penting dalam prosesnya melibatkan pemasok, konsultan dan akademisi. Prediksi umur layan komponen bangunan pada penelitian ini terbatas pada umur layan acuan didapat pada publikasi dari studi sebelumnya serta kajian dari klaim produsen dari produk komponen bangunan. Penelitian selanjutnya harus ditekankan pada kajian umur hidup spesifik pada tiap komponen material dengan mempertimbangkan metode faktor dalam menentukan estimasi umur layan yang disaran oleh ISO 15686.

\section{Ucapan Terima Kasih}

Terimakasih kepada kontraktor yang telah menyiapkan data dan responden yang partisipasi dalam studi ini. Terima kasih kepada Prodi TS, MTS, LPPM Universitas Atma Jaya Yogyakarta yang telah mendukung publikasi studi ini. Publikasi studi ini adalah bagian dari keluaran hibah Ristekdikti 2019. Terimakasih atas saran dari para reviewer jurnal.

\section{Daftar Pustaka}

Blank, L. \& Tarquin, A. (2005). Engineering Economy. McGraw-Hill Int. Ed.

Building and constructed assets - Service life planning - Part 1: General principles and framework. ISO 15686-1. 2011., ISO Geneva

Building and Constructed Assets: Service Life Planning - Part 5: Life Cycle Costing. ISO 15686-5. 2008., ISO Geneva

Building and Constructed Assets: Service Life Planning - Part 8: Reference Service Life and Service Life Estimation. ISO 15686-8. (2008), ISO Geneva.

Ervianto, W.I (2012). Selamatkan Bumi melalui Konstruksi Hijau. Yogyakarta: Penerbit Andi

Fuller, S. K., \& Petersen, S. R. (1996). NIST Handbook 135: Life Cycle Costing Manual for the Federal Energy Management Program. Washington: U.S. Government Printing Office

Ive, G. (2006). Re-examining the costs and value ratios of owning and occupying buildings. Building Research \& Information, 34(3), 230-245

Junus, T.D \& Fitria, D. (2015). Pengambilan Keputusan Investasi dengan Metode LCCA, Sustainability Division PT ASDI Swasatya

Kamagi, G.P., Tjakra, J., Langi, J.E.C., \& Malingkas, G.Y. (2013). Analisis Life Cycle Cost pada Pembangunan Gedung (Studi Kasus: Proyek Bangunan Rukan Bahu Mall Manado). Jurnal Sipil Statik, 1(8), 549-556

Kaming, P.F., \& Marliansyah, J. (2015). Implementation of Life Cycle Costing: a case of hostel building at Kediri, Eastern Jawa, Indonesia. Applied Mechanics and Materials 845, 326-331

Kaming, P.F. (2017). Implementation of Life Cycle Costing for a University Building. Indonesian Journal of LCA and Sustainability, 1(1), 29-38. ILCAN \& LIPI, Indonesia

Kirk, S. J., \& Dell'Isola, A. J. (2003). Sustainability/LEED and Life Cycle Costing - Their Role in Value Based Design Decision Making. LEED

Kirk, S.J., \& Dell'Isolla, A.J. (1995). Life Cycle Costing for Design Professional, $2^{\text {nd }}$ Ed. McGraw-Hill 
Life-Cycle Cost Analysis for Buildings Is Easier Than You Thought. USDA Forest Service, Technology and Development. (2013, September 26)

Pedoman Pemeliharaan dan Perawatan Gedung. Permen PU No 24/PRT/2008, DPU Dir Cipta Karya, DPU

Standard Practice for Measuring Life Cycle Costs for Building Systems. ASTM E917-17

Zainal, A. Z. (2005). Analisis Bangunan: Menghitung Anggaran Biaya Bangunan., Jakarta: PT. Gramedia Pustaka Utama 
